\title{
Jabra Ibrahim Jabra's In Search of Walid Masoud. A Polyphony of (Un)Orchestrated Opus
}

\author{
Ibrahim A. El-Hussari*
}

\begin{abstract}
This paper makes use of Mikhail Bakhtin's notion of polyphony to approach In Search of Walid Masoud, a novel written in Arabic by the Palestinian writer Jabra Ibrahim Jabra in 1978 and translated into English by Roger Allen and Adnan Haydar in 2000. It is the story of the mysterious disappearance of the protagonist Walid Masoud who does not flesh out as a character in his own right although he fills the world of the novel from beginning to end. As the novel hosts multiple characters with distinct voices, each telling his/her own version of the reminisced memories with the protagonist, there is a need to stitch up these parts in search of a possible vision lurking in the offing of the tale. In this context, Bakhtin's polyphony is used to deconstruct and reconstruct the fictional world which Jabra must have pedantically created in this fragmentary novel to send a holistic, non-fragmentary message. Pulling the threads of the various voices of characters rehashing nonidentical pieces of the jigsaw puzzle that makes the story of the physically absent hero, this paper demystifies the un-orchestrated polyphonic ambiguities in order to unify the seemingly disconnected events that make the plotline of Walid's story and his baffling disappearance from the outset of the novel. In particular, this study looks at the narrative technique used by Jabra to create from a variety of reminisced and shredded personal narratives a totality of a clear-cut vision at the centre of which stands one image epitomizing the drama of a national saga that is worth-telling. Focusing on the impact of Jabra's narrative technique, this paper explores areas long viewed by some literary critics as marginal and unimportant. To this effect, the paper authenticates the voice of the absented hero as the ever-present figure who excels himself to address his homeland, Palestine, as a reverberating national cause.
\end{abstract}

\section{Introduction}

A multi-talented and perceptive Palestinian man of letters and arts, Jabra Ibrahim Jabra (1920-1994) has gracefully left a memorable imprint on both the Arab and the World literary and cultural scenes. Educated in Jerusalem, Cambridge and Harvard, Jabra stands out as a mold of a prolific writer, a gifted oil painter, an uncompromising literary-and-art critic, a connoisseur of classical music, a professional translator, a creative poet, a modernist novelist, and above all a distinguished educator and university professor. To quote him, "Had I not been all of these at the same time, I would have probably been none of them at all." 1 This statement simply amplifies the assumption that Jabra's bit of genius featuring in his novels and short stories is in no way separable from the other skills which he constantly developed over time almost fairly equally. However, this paper focuses only on one of his sides: Jabra the novelist. It is his narrative talent that makes him stand out amidst his

\footnotetext{
*Professor of English, Lebanese American University, Lebanon.

1. From a dialogue with Jabra I. Jabra in Baghdad, Iraq. The dialogue was conducted in Arabic by Najman Yassin, al-Jamia'a, April 1978, Vol. 8, Issue: 4: 7-12. [My translation]
} 
great Arab contemporary novelists, such as Ghassan Kanafani, ${ }^{2}$ Naguib Mahfouz ${ }^{3}$ and a few others. Jabra's novel, In Search of Walid Masoud (1978), is one of the four great novels shaping his fictional world. It was greatly influenced by the twentieth-century modernist trends and non-traditional narrative techniques attempted and perfected by the pioneers of the Western novel, such as Franz Kafka in Austria, James Joyce in Ireland and William Faulkner in the United States of America.

Jabra translated William Faulkner's masterpiece The Sound and the Fury (1929) into Arabic in 1954. Although literary translation poses challenges that cannot be squarely met even by professional translators in the field, Jabra seems to have succeeded to create, in his novel In Search of Walid Masoud (1978), a fictional world that does not only simulate but also excels the fine technical threads of the complex narrative that Faulkner builds in his novel The Sound and the Fury. More specifically, Jabra employs a multiple focus of narration to play up the enigmatic life-story of a single character whose missing physical existence gradually coheres into a cryptic and fascinating portrayal of a full-blown character of flesh and blood. Like Faulkner, who uses a fragmentary language that reflects the disjoined voices doing the narration of the central scene of the Compsons' household story in The Sound and the Fury, Jabra pulls the threads of the various narrative voices telling the story of the missing Walid Masoud (henceforth Walid) into a coherent whole with a thematic value underlying yet unifying the disconnected events that make the plotline of Walid's mysterious disappearance. This paper looks at the narrative technique used by Jabra to create from a variety of reminisced and shredded voices a totality of a clear-cut vision at the centre of which stands one image epitomizing a rightful national cause that is worth-telling. The national cause is that of Palestine, the only home for the Palestinian people. This homeland has been usurped and renamed, a great number of its population dispossessed, cheated and forced to flee their birth-right space and property across borders only to discover soon enough that they have become homeless refugees -- Jabra one of them -- in the neighboring countries and the world at large. ${ }^{4}$ This turning point in the history of Palestine and the Palestinian population has by all means yielded massive tragic consequences.

2. A Palestinian journalist and novelist influenced by Jabra's translation of Faulkner's The Sound and the Fury, and that influence appears in his novel All That's Left to You (1966).

3. An Egyptian Nobel Prize winner for Literature also influenced by Jabra's translation of Faulkner's The Sound and the Fury, and that influence appears in his novel Miramar (1976).

4. Roza I. M. El-Eini, Mandated Landscape: British Imperial Rule in Palestine, 1929-1948 (London: Routledge, 2006); Gideon Biger, The Boundaries of Modern Palestine, 1840-1947 (London: Routledge, 2004); Guillaume Vareilles, Les Frontieres de la Palestine, 1914-1947 (The Frontieres of Palestine, 1914-1947) (Paris: L'Harmattan, 2010). 
The tragedy was orchestrated by a number of accomplices: the British colonial administration, the Zionist immigrant militia forces, and the inexplicable silence of some newly-independent Arab states neighboring Palestine. This was abruptly done in the wake of the British ending their mandatory rule over Palestine (1920-1948) on May 14, 1948. Bitterly and resentfully enough, the first act in the Palestinian drama took place under the eyes of the British mandatory police force operating in Palestine then. Thousands of homeless Palestinians in unwanted diasporas would keep telling their own exilic stories. Jabra, himself, would also use his sharp memory to blow life into the not-yetdimming familiar past by concocting tales in which every geographical detail described thereof is solid and lively enough to keep Palestine in history.

For Jabra, as the bulk of his work ${ }^{5}$ shows, Palestine remains a living entity in its peoples' shared memories and national history, their incessant aspirations to return home and reunite with their broken families, as well as their uncompromising will to maintain a national identity resistant to oblivion. Jabra's novel In Search of Walid Masoud is an indirect dramatization of Palestine as a just cause through the discourses of all those characters in the tale who inadvertently take part in pulling together the threads of the jigsaw puzzle as they rehash their reminisced episodic relationships and points of view that are alike when it comes to the last scene although often in sharp contrast with that of the absented protagonist of the tale, Walid Masoud.

Accordingly, this paper studies the significance of the polyphonic form encompassing the multi-sided world of In Search of Walid Masoud. The artistic end of polyphony in this regard is to show both interaction and interdependence of several distinct voices that are doing the narration and simultaneously, yet unintentionally, reshaping Jabra's vision while playing an un-orchestrated opus in honor of art. The opus thus produced by that polyphony seems to be carrying Jabra's voice and message to the world. Such an approach to Jabra's polyphonic novel would, therefore, be useful in the context of analyzing the author's vision captured not only through the lens of one character's single consciousness but also through the scope of a plurality of consciousness for a clearer dialogic understanding of the constituents of the world depicted within the unity of the novel.

\section{Literature Review}

As a concept taken up by literary theory, speech act theory and linguistics, polyphony refers to the simultaneity of points of view, voices within a

5. Jabra's oil painting is also included. 
particular narrative plane. ${ }^{6}$ Polyphony also evokes a number of interpretations in the fields of art, culture and literary criticism. In music, for example, polyphony is a style of musical composition employing two or more simultaneous, but relatively independent, melodic parts, lines, or voices to shape the overall sound of a certain work of music. ${ }^{7}$ In culture, polyphony refers to the characteristic discourse of a diversified cultural context which reflects distinctive linguistic features of voices of various social-class groupings. In literary criticism, and more particularly in the area related to the study of the novel as a type of popular narrative art, Bakhtin's polyphonic theory marked a turning point in the field of literary criticism. In his The Dialogic Imagination, Bakhtin $^{8}$ illustrates polyphony as both concept and theory where the authorial voice and position are redefined in a literary narrative. The author's voice, that is, turns out to be one amongst other voices standing for characters, where each voice is viewed as an independent melody that fits within the harmonious opus produced in the multifarious world created. In contrast to homophony where the author is the mastermind of the whole narrative game and his voice is the only one audible, polyphony allows for a multiplicity of independent voices which are combined in a unity of a higher order.

In practical terms, the Bakhtinian approach to Dostoevsky's novels says it all. Bakhtin describes the main characters in Dostoevsky's novels as having very different and often conflicting points of view and discursive voices. However, they create the unique world of poetics without being even dialectical. That is, in their spatial and temporal context, these characters maintain the unity of their being together through pluralism of ideas, for there is no universal ideology that drives all these characters. They are equally independent. ${ }^{9}$ The author does not place his narrative voice between the character and the reader; characters can subvert and rebel or break loose from the grip of the author, thanks to their autonomous nature in a pluralistic medium of individual consciousnesses. In other words, truth is established by addressivity, engagement and commitment in a particular context. ${ }^{10}$

As polyphony deals with a diversity of individual voices, which are artistically orchestrated, the polyphonic nature of the novel arises from the interaction of those distinct voices and discourses. The novel in this sense is

6. Mikhail M. Bakhtin, Problems of Dostoevsky's Poetics, ed. and trans. Caryl Emerson (Minneapolis: University of Minnesota Press, 1984).

7. Merriam-Webster Dictionary.

8. Bakhtin, The Dialogic Imagination: Four Essays, ed. Michael Holquist and trans. Caryl Emerson and Michael Holquist (Austin: University of Texas Press, 1981).

9. Bakhtin, Problems of Dostoevsky's Poetics.

10. Ibid. 
constructed as a great dialogue among unmerged souls or perspectives. ${ }^{11}$ In the same vein, David Lodge argues that a polyphonic novel is a novel in which "a variety of conflicting ideological positions are given a voice and set in play ... without being judged by an authoritative authorial voice."12

For Bakhtin, polyphony in literature essentially means "an attempt to refute the objectification of man through the pluralistic intervention of the dialogue."13 The dialogic nature of the text is the significant unifying element without which "the harmonic principle of the polyphonical [ic.] accomplishment would disintegrate into anarchic cacophony."14 Artistically, polyphony shows that the world of the whole text is greater than the worlds constituted by its parts. In Jabra's In Search of Walid Masoud, there is no effort on the part of the author to reconcile and conflate the various versions into a single, definitive one. None of the characters, alone, holds the absolute "truth" about Walid Masoud, the protagonist, even though each may, implicitly or explicitly, claim it. Within the novel, the recurring events achieve a plurality of meaning through their representation by simultaneous, distinct consciousnesses which are polyphonically contrasted in the text. In this sense, Jabra must have made an innovative, strategic achievement within the modern and contemporary Arabic novel during the 1960s and 1970s by replacing the omniscient voice of the author/narrator with multiple voices doing the narration. Dialogue mobilizes the course of transition from the fragmentary pieces of the jigsaw puzzle to the holistic image these pieces represent to form an ensemble. In this connection, the interactive reader can be part of this game in order "to recreate and, in so doing, renew the text."15

Does this mean that Jabra's In Search of Walid Masoud as text is open to an endless number of dialogic possibilities? Does this novel foster and address an open-ended dialogue in favor of a further search - a search for the "truth" which does not appear to the various characters as identical? The opening and the closing lines of this narrative text betray signs in the direction of tracing two types of journey: the first one is a quixotic journey through the psychic and political landscape of the compelling central character who is "intensely present yet irretrievably lost."16 The second journey is a hopeless search, not only for the missing Walid Masoud, but also for the foggy world hosting the lost generation

11. Athina Karatzogianni and Andrew Robinson, Power, Resistance and Conflict in the Contemporary World: Social Movements and Hierarchies (London: Routledge, 2010).

12. David Lodge, After Bakhtin: Four Essays on Fiction and Criticism (New York: Routledge, 1990), 86.

13. M.-Pierrette Malcuzynski, "Polyphonic Theory and Contemporary Literary Practices," Studies in 20th Century Literature 9, no. 1 (1984), 77.

14. Ibid., 78.

15. Ibid., 86.

16. Samah Selim, "Jabra's In Search of Walid Masoud," Institute for Palestine Studies 31, no. 2 (2006), 89 . 
represented by a few bourgeois intellectuals doing the narration and telling more than one story.

\section{The Story}

Although the central event that triggers off a chain of other events in Jabra's In Search of Walid Masoud is explicitly stated in its title and the opening lines endorsing that event, the focal point of the story is somewhere else. The search, assumingly the central event, is soon eschewed in favor of character delineation and the dramatic role of memory replete with intricate personal and cultural relationships. It is Walid's memory and the memories of the rest of characters who do the narration that really make the novel the complex text it is, the starting point being the baffling sudden disappearance of Walid Masoud.

It is on the road leading out of Baghdad in the direction of the Syrian desert that Walid Masoud disappears one dark night in the early 1970s. An audio-tape recording his own voice is left in the car. Listening to that tape, Walid's friends start to search arduously for him, not in the physical world around them but within their own memories and their experiences with him. As they partake in this activity, they do not only probe the mysterious disappearance of Walid as an end in itself, but they also probe all the memories that store a variety of tales and reflections on and about this enigmatic character. The closing scene, however, restores the central event, only to imply that Walid's absence has been in the interest of his constant presence in the heart of his national cause, the occupation of Palestine.

\section{The Double Journey}

The opening lines of the story are poetic and suggestive. They initiate a move towards the redemptive power of writing through Walid's wish to bring memory back to life.

If only there were an elixir for the memory, something that could bring events back in the order they happened, one by one, then turn them into words that would cascade out into paper! ${ }^{17}$

The closing note embedded in the following lines that keep recurring here and there in the novel betrays signs of another possible reading: that Walid's

17. Jabra I. Jabra, In Search of Walid Masoud, trans. Roger Allen and Adnan Haydar (Syracuse: Syracuse University Press, 2000), 1. 
personal vision is still blurring out and his wish to write it up is still going unfulfilled.

... no no no that's not what I wanted to say even though I did want to say some of it when everything I've already said is merely marginal and the main text is missing so let me try again ... ${ }^{18}$

Within this framework of a seemingly endless search, Jabra sketches a double journey into the memories of Walid and the other characters. It is the audio-tape left in the deserted car that sets off a lot of things in motion, compelling Walid's friends to give their own accounts of the protagonist -- each account inaccessible to the others. All those accounts remain fragmentary for they are subjectively rendered. Accordingly, it is the reader's irksome role to piece all these accounts together for the approximation of a fuller sense of the novel. Hence the deconstruction and the reconstruction of the text.

If the first journey implied through the tape-recorded monologue should say anything at all, that thing would be filtered through the memories of the other characters. Walid's tape delivers rampant, disconnected shreds of his life, but all these shreds are mediated by the other narrators, albeit in different versions. With each of the narrators recalling one part or more of Walid's life-story, the reader is compelled to dive with a waver into those memories to retrieve who and what Walid was. His compiler, Dr. Jawad Husni, can hardly decipher a clear message from the tape although he has played it several times.

For some reason I can't pin down, I got the impression Walid was out to confuse us all with this "final" tape of his, or maybe he wanted, for the last time, to be frank with all of us, to put his cards on the table, so to speak. ${ }^{19}$

Issa Nasser, an old carpenter and a native of same Palestinian city, recalls Walid's childhood in Bethlehem and his departure for Italy to study theology to become a priest but Walid changes his mind and studies literature at Cambridge. Dr. Tariq Raouf, a psychiatrist, sees Walid as an Oedipal case whose attachment to the image of woman-as-mother persists in almost every relationship with a woman. Amer Abdel-Hamid, an architect, remembers him as a poet with lofty and refined expressions. Women characters have their own say in this regard. For instance, Maryam al-Saffar, a historian, and Wisal Raouf, the young journalist and researcher, both lament his loss as their intimate ex-lover. However, Wisal insists that Walid has not died; she claims that he is still alive and that he has joined the Palestinian Resistance movement in Lebanon. In short, through the eyes of all those characters, Walid's image stands out from the crowd as a revolutionary

18. Ibid., 20-21.

19. Ibid., 7-8. 
soul who dreams and fights at the same time to change the world through love, rebellion and politics.

The journey in the memories of this circle of friends goes beyond the hard-toretrieve parts of Walid's past, only to touch upon speculation. Speculations regarding Walid's fate vary. To mention only a few, Ibrahim al-Hajj Nawfal would see him as kidnapped and then as a dead man in Lebanon. Wisal believes he is alive working in Palestine, perhaps to avenge the death of his son, Mawan, a young freedom fighter who has lost his life in a battle with an Israeli army unit in an Israeli-occupied Um El-Ain village in northern Palestine. However, all these speculations seem to be no innocent talk; they must be serving each character's psychological needs. Hence, the second journey into the psychological states of mind of the other characters as understood through the lapses of their own memories.

Dr. Jawad Husni, the serious sociologist and academician who frames the tale, opens the novel by reflecting on Walid's tape entrusted to him in person: "We remain the playthings of our memories."20 Then the tape is played for all of Walid's narrow circle of friends at a garden party hosted by the architect Amer Abdel-Hamid. Having listened to the grabbled tape on which a lot of things are stuffed and interwoven, such as childhood memories, spiritual ruminations, love adventures, Shakespeare's Hamlet, poetry, and many other things, each one of those friends would voice different reflections on the tape, for Walid's voice has haunted them all and compelled them to react.

The search for the mysterious disappearance of Walid has indirectly acquired another dimension, a parallel search for the self as the reader dives into the complex lives of those characters themselves. As the reader finds himself sliding into the world of this classy group of people, both men and women, he soon encounters a bunch of Baghdadi bourgeois intellectuals divided between two conflicting affiliations: their social class and their political persuasions. We also encounter all those characters in the plane mirrors that reflect their daily behavior and intricate relationships as well as their association with the compelling character of Walid.

With all those characters, Walid's language of the tape-recorded monologue addresses the need for a dialogue, a reaction. Language is dialogic, as Bakhtin illustrates, for "To be heard is in itself a dialogic relationship. The word wants to be heard, understood; it wants to be an answer as it implies back to a question, and so on."21 This polyphonic novel allows for a wider vantage point through which the reading critical mind can analyze personal attitudes as discursive spaces when conflicting voices engage in a contest for audibility and power. None of the characters doing part of the narration can keep her/his sobriety all the way to the end; each of them soon slips unto the unconscious to uncover a double

20. Ibid., 1.

21. Bakhtin, Problems of Dostoevsky's Poetics, 301. 
face shaping their experiences and the network of their relationships. Even Dr. Jawad Husni, the sociologist entrusted with Walid's personal papers and documents to compile a biography, admits that his wish to keep a bright intellectual stature through framing Walid's life-story still needs much reworking. He expresses an anxiety over the impossibility of deciphering, rearranging and composing into narrative form the entirety of a life like Walid's.

I wonder if I'll ever reach a definite conclusion about Walid. Can there ever be a definite conclusion about any event in life, let alone a man's life as a whole?22

Like Jawad Husni, all the other characters involved in presenting other versions of Walid's eventful life as they know it, lapse into their own fantasies and soon resign the arduous job of going further into the search. In fact, each one of them tries to polish that dark area which the search for Walid has provoked or at least awakened in them. This assumption, however, does not apply to Walid's son, Marwan, who seems to have nursed no hidden agendas or uneasy memories. Marwan has unequivocally chosen his way back to Palestine through joining one of the Palestinian armed struggle liberation movements working from Lebanon. That is, he has got no illusions about his people's national cause and their unalienable right to return home..$^{23}$ His martyrdom in the battlefield is the clearest message ever voiced throughout the novel. Hence, Marwan is not part of the group of narrators whose discourses with and about Walid and other topics are grounded in ambiguous conflict. One of the possible options which Walid, as assumed by Wisal Rauf, might have taken on the eve of his disappearance from the scene is likely to be Marwan's. The other search routes attempted by the other characters seem unlikely or less likely to pay off.

\section{Impact of Memory}

Novels that use memory as a key element of the narrative text are not rare in literature. ${ }^{24}$ In In Search of Walid Masoud, memory plays a dramatic role as regards plot build-up and character revelation. Regarding plot, memory is viewed as an opportunity for the illumination of the past in the present. Moments held dear by Walid, especially the Bethlehem memories, are tape-recorded to punctuate the main text. By so doing, Jabra is expanding his narrative text and adding an extra dimension to the plot. The other characters, who dive into their memories while recalling their own versions of Walid's story, also add more layers to the already complex plot structure. In brief, the incorporation of memory in the narrative text

22. Jabra, In Search of Walid Masoud, 288.

23. Ibid.

24. See Marcel Proust's seven-volume novel In Search of Lost Time, 1908-1922. 
grounds it in some sort of identifiable time frame from which the reader can, with much labor, follow the progression of the story..$^{25}$

Memories also function in the process of character revelation. The various individual memories referred to, while the main text is in progress, illuminate the inner selves of the narrators and invite emotional resonance with the readers. All the character-narrators, except for Marwan, are to some varied degrees intrigued in this game of remembrance. Batchen ${ }^{26}$ argues that memories "are nostalgicgripped refusals to be erased or forgotten." 27

\section{Conflicting Discourses}

In In Search of Walid Masoud, the protagonist keeps moving between two conflicting worlds. One of these worlds belongs to the past, to Walid's childhood and boyhood in Bethlehem, Palestine, which his memory sustains and pushes to the surface every now and then; the other belongs to the present, to his world with the circle of his classy and intellectual friends where they agree and disagree over many issues. However, if there is a clear cutoff with them for good, it is in the first world, his world, where memory reworks out the image of Walid as a happy child with aspirations. The present world arguably sets all characters apart despite their frequent gatherings. Hence, it is a source of anxiety over a lot of things: culture, art, language, politics, women, commitment, etc. If the text is replete with an atmosphere of anxiety on the part of most of the characters, including women, part of that anxiety lies in the making of Walid's image which exists in the eyes of all narrators not only as "an ideal uprooted Palestinian" but also as an unfinished text that keeps expanding. The portrait of Walid, as painted by his circle of friends, does not show him as an ideologue or populist with a loud voice. It shows him as a quiet man but also as a powerful agent of change, a messenger who might have come too soon or perhaps too late. In this regard, Edward Said emphasizes this voice of the visionary individual over the voice of "mass institutions." 28 The text does say it so flatly: in a world where words get "pulverized," the only room left for the exile Palestinian, like Walid, is to recall his childhood memories in Bethlehem, Palestine, to nurse his daydream as a child with a vision:

25. Roland Barthes, Mourning Diary, trans. R. Howard (New York: Hill and Wang, 2010); Geoffrey Batchen, Forget Me Not: Photography and Remembrance (The Netherlands: Princeton Architectural Press, 2004); Jens Brockmeier, "Remembering and Forgetting: Narrative as Cultural Memory," Culture and Psychology 8, no. 1 (2002).

26. Batchen, Forget Me Not: Photography and Remembrance.

27. Barthes, Mourning Diary.

28. Edward Said, Reflections on Exile and Other Essays (Cambridge, MA: Harvard University Press, 2000). 
I perched there between the branches, eating green almonds, watching people pass to and fro below me ... I wanted the world to change to my will...29

It is in this part of the text that Walid and his companions depart. Where he is involved in the national cause, they are not although they understand it. The engagement in personal acts of remembrance "is itself a political act, and to record and transmit one's memories in written or spoken form is akin to engage in an insurrectionary activity that defies the prohibition of self-narration imposed by Zionist historiography." 30 In the other part of the text, the present world, where Walid has left a footprint, the others find themselves, ironically so, in constant search for themselves in the missing Walid, he being the "other." They seem to be projecting all their miseries and discontent on the "other," on that spot left by Walid and recorded on his tape. This image is best expressed at the end of the novel, Chapter 12, through which Jawad Husni is trying to add a closing note to the novel.

... we still have to ask the question: who was it they were actually talking about? Was it a man who occupied their minds and feelings at a certain point in time, or was it themselves and the fancies, frustrations, and uncertainties that beset them in their own lives? Were they in fact the mirror, with Walid serving as the face surveying them from its depths? Or was he the mirror, and their faces the ones rising up, while they, perhaps, weren't even aware of it? ${ }^{31}$

\section{Concluding Remarks}

Jabra Irahim Jabra's novel In Search of Walid Masoud is a polyphonic text in which a variety of consciousnesses send different messages in different directions as they deal with one central issue: the mysterious disappearance of one of their remarkable friends, Walid Masoud. However, what remains common to all of them and relatively shared by all is a bourgeois touch and a narcissistic tendency towards self appraisal or self-lamentation as they mediate that enigmatic issue. They are all mediators who finally blame it on their inability to put their memories and experiences with Walid into orderly and meaningful texts. That is why, the search for Walid yields no result; in fact, there is a hint that the story is unfinished, exactly like Walid's unfinished autobiography. This novel, therefore, comes to an abrupt halt, not a logical ending. This simply implies that the power of the Arab intellectual production in the wake of the $1967 \mathrm{Naksa}^{32}$ is explored and tested in the novel as limited and dysfunctional. The polyphonic text furnishes

29. Jabra, In Search of Walid Masoud, 130.

30. Said, "Permission to Narrate," Journal of Palestinian Studies 13, no. 3 (1984).

31. Jabra, In Search of Walid Masoud, 276.

32. Arabic term for defeat. 
Vol. 6, No. 2 El-Hussari: Jabra Ibrahim Jabra's In Search of Walid Masoud...

the stage for multiple ways of approaching the central event, but it seems that reading that event has failed as a mode of accessing the truth. ${ }^{33}$ (Johnson 2009).

\section{Bibliography}

Bakhtin, Mikhail M. Problems of Dostoevsky's Poetics. Edited and Translated by Caryl Emerson. Minneapolis: University of Minnesota Press, 1984.

Bakhtin, Mikhail M. The Dialogic Imagination: Four Essays. Edited by Michael Holquist and Translated by Caryl Emerson and Michael Holquist. Austin: University of Texas Press, 1981.

Barthes, Roland. Mourning Diary. Translated by R. Howard. New York: Hill and Wang, 2010.

Batchen, Geoffrey. Forget Me Not: Photography and Remembrance. The Netherlands: Princeton Architectural Press, 2004.

Biger, Gideon. The Boundaries of Modern Palestine, 1840-1947. London: Routledge, 2004.

Brockmeier, Jens. "Remembering and Forgetting: Narrative as Cultural Memory." Culture and Psychology 8, no. 1 (2002), 15-43.

El-Eini, Roza I. M. Mandated Landscape: British Imperial Rule in Palestine, 1929-1948. London: Routledge, 2006.

Jabra, I. Jabra. In Search of Walid Masoud. Translated by Roger Allen and Adnan Haydar. Syracuse: Syracuse University Press, 2000.

Johnson, Rebecca Carol. "The Politics of Reading: Recognition in Jabra Ibrahim Jabra's In Search of Walid Masoud." In The Poetics of Narrative: Interdisciplinary Studies, edited by Philip F. Kennedy and Marilyn Lawrence, 178-192. New York: Peter Lang, 2009.

Lodge, David. After Bakhtin: Four Essays on Fiction and Criticism. New York: Routledge, 1990.

Malcuzynski, M.-Pierrette. "Polyphonic Theory and Contemporary Literary Practices." Studies in 20th Century Literature 9, no. 1 (1984).

Karatzogianni, Athina, and Andrew Robinson. Power, Resistance and Conflict in the Contemporary World: Social Movements and Hierarchies. London: Routledge, 2010.

Said, Edward. "Permission to Narrate." Journal of Palestinian Studies 13, no. 3 (1984), 27-48.

33. Rebecca Carol Johnson, "The Politics of Reading: Recognition in Jabra Ibrahim Jabra's In Search of Walid Masoud," in The Poetics of Narrative: Interdisciplinary Studies, ed. Philip F. Kennedy and Marilyn Lawrence (New York: Peter Lang, 2009), 187-192. 
Said, Edward. Reflections on Exile and Other Essays. Cambridge, MA: Harvard University Press, 2000.

Selim, Samah. "Jabra's In Search of Walid Masoud." Institute for Palestine Studies 31, no. 2 (2006).

Vareilles, Guillaume. Les Frontieres de la Palestine, 1914-1947 (The Frontieres of Palestine, 1914-1947). Paris: L'Harmattan, 2010. 
